\title{
СУМНА ІНФОРМАЦІЯ
}

\section{ТАДЕУШ ДОКТОР}

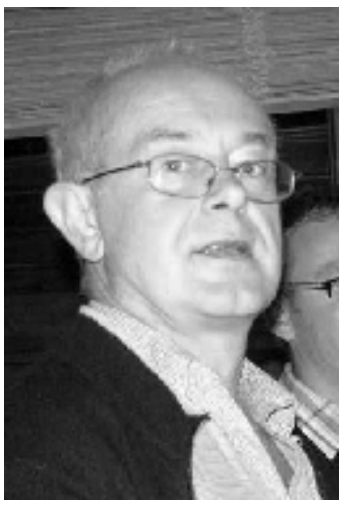

Польське релігієзнавство зазнало невтішної втрати. 19 червня цього року несподівано помер відомий польський вчений, соціолог релігії із світовим ім'ям професор Тадеуш Доктор. Його добре знали українські колеги, неодноразово зустрічаючись на конференціях, читаючи його праці, які, безумовно, є солідним внеском до світової релігієзнавчої наукової скарбниці. Його книги «Культові рухи Польщі», «Релігійні і парарелігійні рухи в Польщі», «Релігійний $\mathrm{i}$ моральний плюралізм в Польщі» та інші $\epsilon$ в український бібліотеках, власних книгозбірнях його українських колег. Професор Доктор відомий в Польщі i за іiі межами як висококваліфікований фахівець, чий доробок з питань нових релігійних течій $\epsilon$ значимою спадщиною не тільки польської релігієзнавчої думки.

57-річне життя Т.Доктора від часу його студіювань філософії та психології в Католицькому університеті Любліна було сповнено живою зацікавленістю релігією, що виливалося в його наукові статті, дисертації, виклади, які він мав у Варшавському університеті перед студентською аудиторією. Він прислужився і процесу інституційного становлення декількох професійних асоціацій, особливо плекаючи Міжнародну асоціацію 3 вивчення релігії в Східній і Центральній Європі, до якої входять багато українських релігієзнавців.

Ми сумуємо 3 приводу втрати нашого польського колеги, з яким були пов' язані тривалий час не тільки спільними проектами, творчими задумами, але й дружніми стосунками, оскільки Тадеуш був цікавою, творчою, щирою, доброю людиною, вболівав за долю не тільки польської, але й української науки. Висловлюємо свої співчуття родині Т.Доктора та його колегам. 